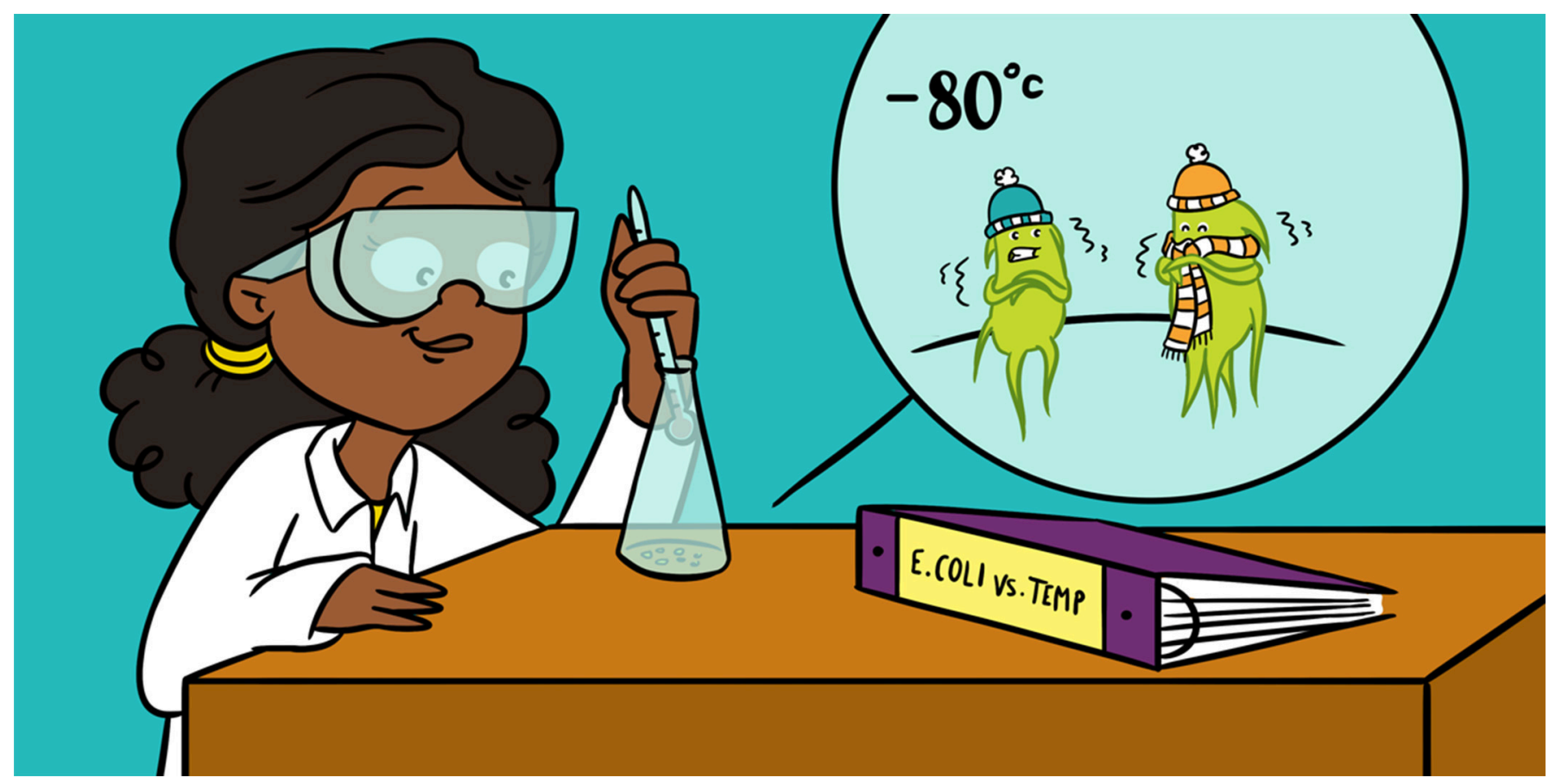

\title{
EVOLUTION IN A BOTTLE
}

\section{César Aguilar*}

Laboratorio Nacional de Genómica para la Biodiversidad, Unidad de Genómica Avanzada, Centro de Investigación y Estudios Avanzados del Instituto Politécnico Nacional, Guanajuato, Mexico

\section{YOUNG REVIEWERS:}

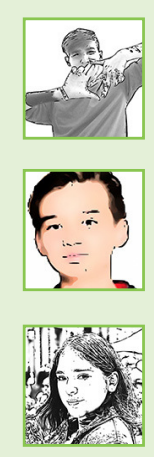

\section{CARLOS}

AGE: 16

DANIEL

AGE: 14

MARÍA

JOSÉ

AGE: 14
Evolution is the process that originates changes in living beings over time, which allows them to adapt to different environments. Evolution has created the big diversity of living things on earth. Using bacteria, scientists are investigating how evolution works, by studying bacterial DNA and its mutations, which are the main cause of the DNA changes that result in evolution. Why did we choose to study bacteria? Well, because they are probably the most well-adapted organisms on earth. They can survive in the most varied and extreme conditions, from underwater volcanoes to Alaskan frozen ground. To conduct this research, a bacterium called Escherichia coli was chosen as the test subject some fascinating experiments that we will describe in this article.

\section{WHAT IS EVOLUTION?}

On our planet, there are microscopic organisms inhabiting almost every corner: bacteria. There are around one billion species of bacteria on earth. What is the reason for this tremendous diversity of bacteria 
Figure 1

Voyage of the H.M.S.

Beagle. (A) In 1831, the

English naturalist

Charles Darwin

embarked on a 5-year

trip on the British

research ship H.M.S

Beagle. The Beagle

explored numerous

places, shown by the

red dots on the map.

Darwin's observations

of the organisms in

these locations showed

interesting patterns in

the distribution and

characteristics of many

organisms, such as

turtles, finches,

mussels, marsupial rats, and platypus, which made Darwin think about adaptation. (B)

The most famous example of adaptation

found by Darwin was

the great diversity of

finch beaks. The beaks

of different finches

seemed designed to

eat the specific food

present in the place

where they lived. Using

all of his observations,

Darwin came up with

the theory of evolution

by natural selection.

\section{EVOLUTION}

In biology, is the change in any trait of an organism. Those changes are derived from mutations over the generations.

\section{MUTATION}

Are changes in the nucleotide sequence of the genes.

\section{GENE}

A defined set of nucleotides. The order and type of these nucleotides determine the functions of a gene.

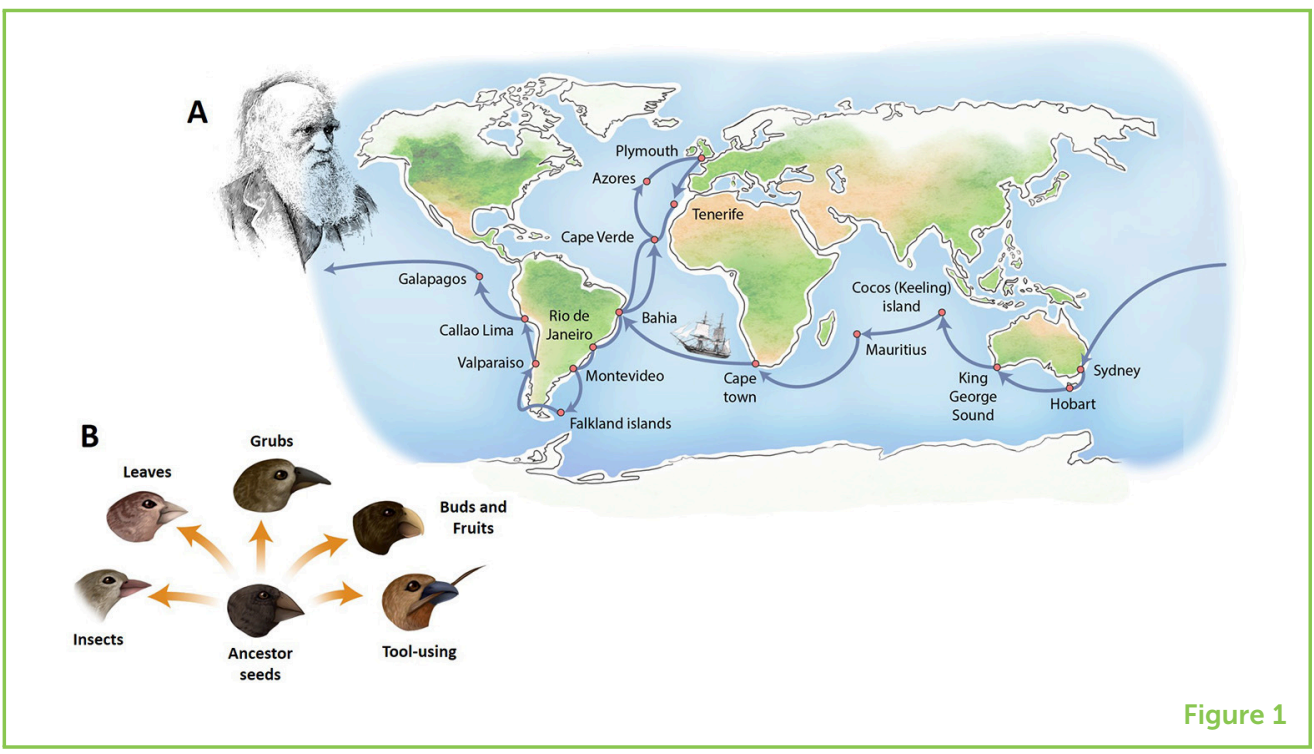

that inhabit our planet? Evolution is the key. The word evolution is used to describe changes in organisms that occur over many generations. In 1831, the English naturalist Charles Darwin embarked on a 5-year trip on the British research ship H.M.S. Beagle. During the trip, Darwin observed interesting patterns in the distribution and characteristics of many living creatures. He reflected that these characteristics were changes that helped the organisms to adapt to the environments in which they lived (Figure 1). This trip helped Darwin to come up with a theory of evolution in which he explained how living organisms change every generation, adapting to the conditions of their environment in order to survive [1].

\section{HOW DOES EVOLUTION HAPPEN?}

A big question that originated from Darwin's theory was how the changes he observed came to be. Today, we know that these changes are ultimately caused by mutations. Mutations are changes in an organism's genes. Genes are instructions that all living organisms possess. Every gene is composed of a unique combination of four molecules called nucleotides: adenine, cytosine, guanine, and thymine. The order of these nucleotides, which is called the genetic sequence, determines the function of each gene. The total of all the genes in an organism is called the genome. The genome contains the information coding for all the characteristics of an organism, so a change in one or more nucleotides of a gene (called a genetic change) can disturb a feature of the organism, like the color of the eyes, its height or the way it processes food. This genetic information is inherited, meaning it is passed on from one generation to another. 


\section{NUCLEOTIDE}

They are four organic molecules called adenine, cytosine, guanine, and thymine that serve as forming units of deoxyribonucleic acid (DNA), the essential biomolecule of all forms of life on Earth.

\section{GENOME}

All the genes that an organism possesses

\section{NATURAL}

\section{SELECTION}

Is the process of slow accumulation of helpful mutations across generations, causing the displacement and ultimately, the extinction of less adapted organisms.
Mutations in genes can happen spontaneously or in response to stress factors in the environment, but regardless of the cause, all mutations are random [2]. This means that the genetic changes can occur anywhere in the genome of the organism. The accumulation of mutations over generations can be helpful, harmful or have no effect on survival. Darwin summarized all these facts in a simple concept: natural selection [1]. Natural selection is the process of slow accumulation of helpful mutations over generations, causing organisms to become better adapted to their environments. Organisms that are less well-adapted will have more trouble surviving than will organisms whose mutations have helped them adapt. When mutations produce significant changes in an organism, they can lead to the development of a new species [1].

\section{BACTERIA ARE GREAT FOR STUDYING EVOLUTION}

The classical way to demonstrate that species change over time is through the fossil record. Fossils show how primitive life formed and, if we find enough fossils, it is possible to observe how an organism has evolved over time. However, if the fossil record is incomplete, it is impossible to see all of these changes or to figure out how the organism evolved. To solve this problem, it would be easier to study evolution directly, by examining all of the genetic changes that happen in each generation. To do this, researchers must first find an ideal organism to study. Bacteria are an obvious choice, because they are easy to cultivate in the laboratory and they reproduce quickly. Escherichia coli is a widely studied bacterium that inhabits the digestive system of humans and other warm-blooded animals (Figure 2). Just to compare, if we wanted to do an evolutionary experiment with humans, we would need to wait, on average, 26 years to have a new generation, while $E$. coli spawns a new generation in 20 min-less time than it takes to get a pizza! Additionally, E. coli has a small genome, making it easy and cheaper to study the actual changes in nucleotides that occur in each generation (Figure 2). In the sections that follow, we will describe some of the experiments scientists have performed, using E. coli, to study the process of evolution in the laboratory.

\section{HOW DO BACTERIA EVOLVE IN RESPONSE TO EXTREME COLD?}

By studying $E$. coli in the lab, one group of scientists hoped to understand how bacteria might adapt to extreme cold. To study this, they devised an experiment in which E. coli was subjected to extreme cold for prolonged periods of time. The experiment consisted of 150 cycles of freezing at $-80^{\circ} \mathrm{C}$ for $22.5 \mathrm{~h}$, and then thawing at room temperature for $1.5 \mathrm{~h}$. The result? The survival of $E$. coli increased; they evolved. When scientists studied the genome of these evolved bacteria, they found mutations that disabled a gene that 
Figure 2

E. coli is a useful organism for evolution experiments. There are several organisms commonly used by scientists to carry out experiments of all kinds. Among the most popular are the plant Arabidopsis thaliana, the rodent Mus musculus, and the simple worm Caenorhabditis elegans. To perform experiments on evolution, however, scientists need an organism with a short reproduction time and a small genome. The $E$. coli bacterium has a reproduction time of only $20 \mathrm{~min}$ ! This fast division rate and its small genome make it perfect for these experiments, in the laboratories all around the world. In this figure, you can see the reproduction rate and genome size (in bp, which stands for base pairs) of humans and the other organisms commonly used for scientific experiments.

\section{LTEE}

It is the acronym of "long-term evolution experiment," which refers to evolution experiments performed for long periods of time.

\section{FITNESS}

How well-adapted an organism is to its environment, which determines how many offspring that organism has

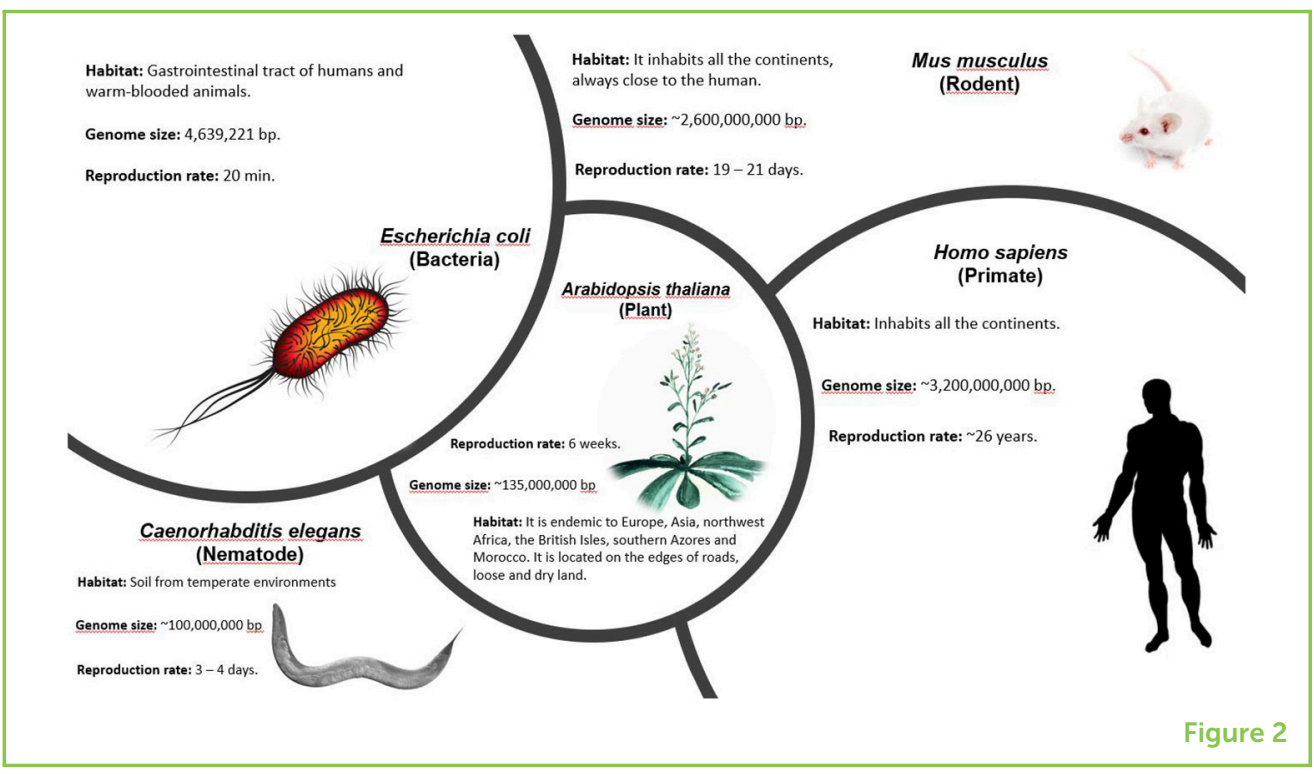

plays a role in the production of cardiolipin, a molecule that makes the outer covering of the bacterial cell sturdy and rigid. Further investigations proved that turning off the production of cardiolipin helped to keep the covering fluid and flexible after freezing, which increased survival [3].

\section{THE MOST AMBITIOUS STUDY OF EVOLUTION}

The most ambitious study of evolution was carried out by a scientist named Richard Lenski. Lenski kept $E$. coli in a special bottle with a liquid, called medium, containing limited nutrients (Figure 3). In this culture medium, the bacteria grew rapidly but depleted the nutrients just as quickly. The bacteria then entered a state of "hunger" that lasted $24 \mathrm{~h}$, after which some of those hungry and stressed bacteria were transferred to another bottle with fresh medium containing the same nutrients. He repeated this process again and again. Over a long period of time, the stress experienced by the bacteria during the process led to the generation of mutations and, consequently, to evolution of the bacterial population. Lenski and his collaborators started this long-term evolution experiment (LTEE) in 1988 and it is still going on [4]. Now, after more than 74,000 generations, a lot of interesting things have happened.

\section{AMAZING FINDINGS IN THE LTEE}

One of the most interesting observations from the LTEE was the remarkable and sustained increase in fitness during the first 5,000 generations (about 2 years). What does that mean? Well, organisms with higher fitness are better adapted to their environment and will tend to produce more offspring compared with their less-fit 
Figure 3

The long-term evolution experiment (LTEE). The LTEE was started in 1988. For this experiment, scientists used a technique called serial transfer, which means that, every day since February 24 of $1988,1 \%$ of an E. coli culture bottle is transferred into fresh culture medium. As time passes, harmful and beneficial mutations are generated. The beneficial mutations result in adaptations that help the bacteria to deal with the famine conditions the population faces daily. This project has not ended yet. Now, after more than 74,000 generations, a lot of knowledge has been obtained.

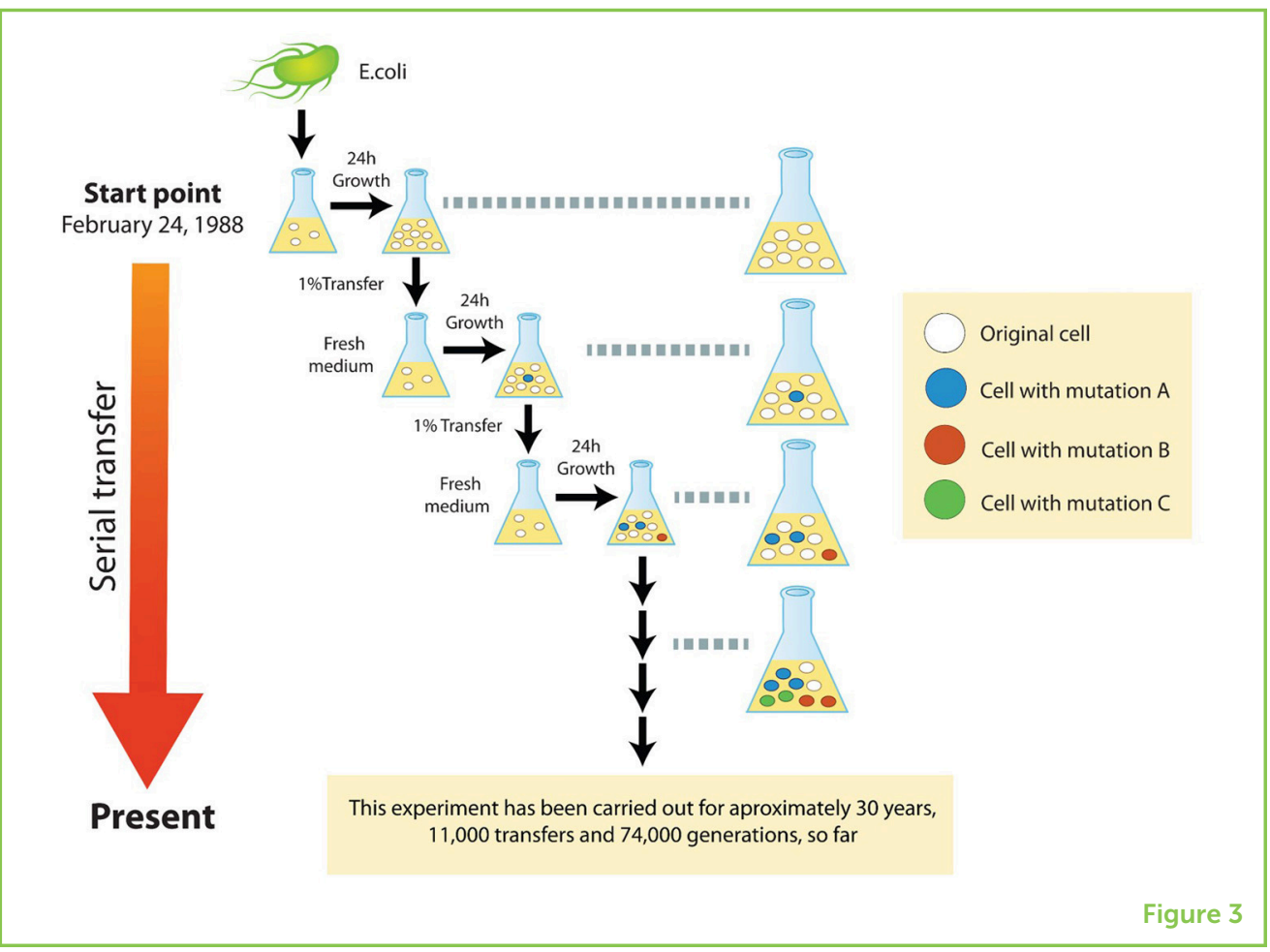

competitors. Lenski observed that, during the first 2 years of the experiment, genetic changes emerged in some bacteria, allowing those bacteria to adapt to the environment, becoming more fit, until they became predominant in the population [4]. Some bacteria adapted to the environment so well that they even lost certain functions that were no longer needed under the experimental conditions. This is similar to what happened to certain animals after hundreds or thousands of years of living in absolute darkness, like in caves. These animals developed an adaptation in which the eyes were eventually lost, since eyes are not useful in those very dark conditions.

Another amazing finding from the LTEE was that, in one experiment, this well-adapted population of $E$. coli was not the only population, but a second minor population co-existed with them because it had evolved the ability to take advantage of acetate, a waste product of the dominant population. This is similar to the relationship between lions and scavenger animals. The lions feed on hunted animals and the remains they leave become food for other animals, like hyenas or vultures.

As previously mentioned, organisms that develop enough genetic and structural changes can become a new species. Could this process have occurred in the LTEE? E. coli possess certain characteristics that make them $E$. coli and not another bacterial species. Among these characteristics is the inability to use a substance called citrate as a food source when oxygen is present. Surprisingly, scientists observed that, 
after 31,500 generations (more than 12 years), one population of $E$. coli began to use citrate as a food source [4]. The evolution of the ability to use citrate is exceptionally rare! How was this possible? Well, E. coli possess all the necessary genes to consume citrate, but those genes are turned off and work only in absence of oxygen. When the scientists observed the genome of the evolved organisms, they realized that, due to certain mutations, those genes were turned on, enabling the $E$. coli to use citrate as a food source. Now, is this citrate consumer a new Escherichia species? What do you think?

\section{CONCLUSIONS}

All the studies of evolution have taught us that life finds a way. For this reason, bacterial genomes can adapt in surprising ways when the bacteria are faced with environmental adversities. This process allows bacteria to colonize new places. E. coli has become the model organism of these evolutionary studies because it grows easily, it has a small genome, and we know a lot about it. The data obtained from these experiments contribute to the study of important evolutionary questions and will allow us not only to understand but possibly to even guide evolution in the future. Can you imagine a future in which it is possible to know all the genes that control the physical characteristics and diseases of an organism? Maybe we are not too far from that, and when it happens, we can help organisms to fight against diseases and possibly find other ways to assist organisms, including humans, in becoming more suited to their environments.

\section{ACKNOWLEDGMENTS}

I thank Daniel E. Bustos Díaz and Diana E. García Hernández for their careful reviewing assistance and English proofread that enhanced the quality of the manuscript. I also want to thank Erika Viridiana Cruz Bonilla for her support in the realization of the figures in this article.

\section{REFERENCES}

1. Darwin, C. R. 1859. On the Origin of Species by Means of Natural Selection, or the Preservation of Favoured Races in the Struggle for Life. London: John Murray.

2. Foster, P. L. 2007. Stress-induced mutagenesis in bacteria. Crit. Rev. Biochem. Mol. Biol. 42:373-97. doi: 10.1080/10409230701648494

3. Sleight, S. C., Orlic, C., Schneider, D., and Lenski, R. E. 2008. Genetic basis of evolutionary adaptation by Escherichia coli to stressful cycles of freezing, thawing and growth. Genetics 180:431-43. doi: 10.1534/genetics.108.091330

4. Barrick, J. E., Yu, D. S., Yoon, S. H., Jeong, H., Oh, T. K., Schneider, D., et al. 2009. Genome evolution and adaptation in a long-term experiment with Escherichia coli. Nature 461:1243-7. doi: 10.1038/nature08480 
SUBMITTED: 07 September 2018; ACCEPTED: 13 May 2019;

PUBLISHED ONLINE: 29 May 2019.

EDITED BY: Angelica Cibrian-Jaramillo, Centro de Investigación y de Estudios Avanzados (CINVESTAV), Mexico

CITATION: Aguilar C (2019) Evolution in a Bottle. Front. Young Minds 7:75. doi: 10. 3389/frym.2019.00075

CONFLICT OF INTEREST STATEMENT: The author declares that the research was conducted in the absence of any commercial or financial relationships that could be construed as a potential conflict of interest.

COPYRIGHT (c) 2019 Aguilar. This is an open-access article distributed under the terms of the Creative Commons Attribution License (CC BY). The use, distribution or reproduction in other forums is permitted, provided the original author(s) and the copyright owner(s) are credited and that the original publication in this journal is cited, in accordance with accepted academic practice. No use, distribution or reproduction is permitted which does not comply with these terms.

\section{YOUNG REVIEWERS}

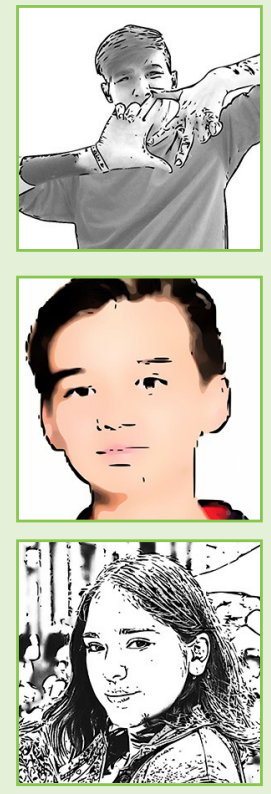

\section{CARLOS, AGE: 16}

My city is located in the middle of Mexico, which is an awesome country to live in because it has such a great culture and its people are just very kind to each other and to other people that are visiting our great country.

\section{DANIEL, AGE: 14}

I love sports, specially football and fencing. My favorite meal is tacos and I also like to go watch and learn about cars.

\section{MARÍA JOSÉ, AGE: 14}

My name is María José, I am 14 years old and I love ballet, I practice it since I was 3 years old, I also love science and I would like to study medicine.

\section{AUTHOR}

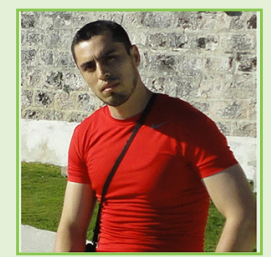

\section{CÉSAR AGUILAR}

I am a researcher in the National Laboratory of Genomics for Biodiversity in Mexico. I have a Ph.D. in Biochemistry and a background in research on bacterial evolution. I love all life forms, especially microorganisms. I have been studying them for more than 10 years: how they survive, how their metabolism works, how they have evolved, and most importantly, how they can help us make this planet a better place. In my free time, I like to do exercise, play soccer, and read. I love my family, coffee, movies, and comics. My favorite superhero is Captain America. ${ }^{*}$ cesar.aguilaracinvestav.mx 